JELTL (Journal of English Language Teaching and Linguistics) e-ISSN: 2502-6062, p-ISSN: 2503-1848

2018, Vol. 3 (1)

www.jeltl.org

\title{
Language Learning: What Factors May Influence It
}

\author{
Yuwinda \\ Universitas Negeri Malang, Indonesia \\ e-mail: ayu.yuwinda@gmail.com \\ Syukur Insani \\ Universitas Negeri Malang, Indonesia \\ e-mail: sunnialhamdulillah@gmail.com
}

\begin{abstract}
As English is an international language, learning English nowadays has become a great deal to be taught in school, especially for society whose English is their second or foreign language. However, learning English may be a psychological burden for learners, particularly learners learning English as a Foreign Language (EFL). Further, the issue in Second Language Acquisition (SLA) field is that although everyone has the same innate language processing mechanisms, certain individual characteristics affect how much individual learners use their processor to learn the language. Some of the learners acquire rapidly through the initial stages of learning a new language while others have repeated failures or meet with very slow progress with limited success. Therefore, it stands to reason that some of them might be anxious in learning L2. Pointing out the effect of anxiety in second or foreign language learning, there are still many other factors that should be taken into consideration to counterpart that issue, such as learners' age, motivation, learning strategies and learning styles to be considered for enhancing language learning. Howbeit, this paper aims to provide other factors that may contribute in acquiring language in a different point of views.
\end{abstract}

Keywords: Language Learning, Anxiety, Age, Motivation, Learning Strategies and Learning Styles 


\section{INTRODUCTION}

Since English has become a lingua franca, learning English nowadays seems like a great consideration to be taught by educational practitioners, not only for other foreign countries which English is a second language but also for Indonesia, as English becomes our foreign language. Yet, to face the modern era and the inflation of the world's economic field and educational field, people need to learn English as well as their compulsory subject in the school, even starting from kindergarten.

Learning the second language, such as English may be a psychological burden for learners, particularly learners learning English as a Foreign Language (EFL). This case happens because English is not their daily interactional language used and it is also not their native language. In line with this, EFL learners are having a lack of exposure towards English. They, somehow, cannot improve their English because they do not have a supported circumstance, interlocutors, and influencing input to enhance their English practice. However, one of the critical issues in the field of Second Language Acquisition (SLA) is the differential of success. Although everyone has the same innate language processing mechanisms, certain individual characteristics affect how much individual learners use their processor to learn the language. Further, in second language learning, it seems like some people have a much easier time of learning the language than others. Some of the learners acquire rapidly through the initial stages of learning a new language while others have repeated failures or meet with very slow progress with limited success. Therefore, it stands to reason that some of them might be anxious in learning L2.

Alluding to the mentioned statement, Troike (2006) clarified that anxiety has received the most attention in SLA research, along with the lack of anxiety as an important component of self-confidence. Besides, anxiety as stated by Javed et al. (as cited in Ariyanti, 2016) is a natural psychological aspect which contains the feeling of fear which sometimes cannot be controlled. It is a normal affective condition that, occurring in excess, may cause humour disturbances as well as alterations in thinking, behaviour, and physiological activity.

Aside from this, Tobias (1986, as cited in Hong Li, 2015) also stated that the arousal of anxiety has posed several potential problems for students learning a foreign language because it can interfere with the language acquisition process and with ongoing cognitive activity. This interference reduces learners' ability to take in information and to learn new material. Additionally, anxiety correlated negatively with measures of L2 proficiency including grades awarded in foreign language classes, meaning that higher anxiety tends to go with lower levels of success in L2 learning. It is also concluded that anxiety experienced in communication in English can be debilitating and can influence students' adaptation to the target environment and ultimately the achievement of their educational goals.

Besides, Dulay, Burt, and Krashen (1982) argued that anxiety could influence what the students receive for further processing. The less anxious the learner, the better language acquisition proceeds and ultimately the more successful they are in language learning. In other words, when students feel anxious, this condition affects them difficult in acquiring the language input due to the affective filter is opened as 
the result of anxiety. Then, it can be concluded that lower anxiety levels and a tendency to be outgoing were connected with the successful of L2 acquisition.

Along with this, Krashen (1982, as cited in Hong Li, 2015) hypothesized that anxiety contributes to an affective filter, which makes individuals less receptive to language input and less expressive of output. Consequently, they fail to absorb the target language message, and language acquisition process is impeded. They are also inhibited with trying to use any L2 they have managed to acquire. Further, Lim (2009, as cited in Hong Li, 2015) found that learners experiencing negative high levels of language anxiety are more likely to drop out of their L2 class and quit their L2 studies.

Regarding the relation between anxiety and learning language, MacIntyre and Gardner (1989, as cited in Hong Li, 2015) examined the learning and production of vocabulary items and found that subjects high in Communicative Anxiety learned and recalled fewer vocabulary items than did those low in Communicative Anxiety. Withal, study conducted by Ariyanti (2016) on factors affecting students' speaking performance found that students feel anxious when performing their speaking. They used to repeat what they said when they made mistakes, owing to they were afraid of making mistakes. Not to mention, Hong Li (2015) also cited several studies related to the anxiety which resulted that learners who experience high levels of anxiety may have difficulty acquiring L2.

Notwithstanding, anxiety-arousal is closely associated with distracting, selfrelated cognition such as excessive self-evaluation, worry over potential failure and concern over the opinions of others; therefore, anxious learners have their attention divided between task-related cognition and self-related cognition, making cognitive performance less efficient. A complete analysis of the subtle effects of language anxiety includes specific task performance and the cognitive process preceding that performance.

Despite the case above, MacIntyre (1995) has also pointed out the effect of anxiety on language learning in that language anxiety could diminish cognitive processing and weaken performance. There is a tendency for students to divide their attention between task-related cognition and self-related cognition when they feel anxious. Accordingly, Eysenck (1979, as cited in Hong Li, 2015) defined that anxiety has shown to impair cognitive functioning, to disrupt memory, to lead to avoidance behaviours, and to have several other effects seen from cognitive psychological perspective. It can be concluded that anxiety-arousal is closely associated with distracting, self-related cognition such as excessive self-evaluation, worry over potential failure and concern over the opinions of others. Therefore, anxious learners have their attention divided between task-related cognition and self-related cognition, making cognitive performance less efficient.

Based on aforementioned views, it could be stated that anxiety not only threatens language processing but also performance. In other words, it has been considered as a negative contribution to language learning. Likewise, $\mathrm{Na}$ (2007, as cited in Hong Li, 2015) found that high anxiety can make learners get discouraged, lose faith in their abilities, escape from participating in classroom activities, and even give up the effort to learn a language well. Therefore, the learners with high anxiety often get a low achievement. 
Pointing out the effect of anxiety in second or foreign language learning, this paper refines on several factors that may also influence the language learning. It discusses the issue by reviewing Hong Li's article (2015) entitled The Effect of Anxiety on University-Level L2 Learner Ability to Recall Items in the Lexicon. Accordingly, Hong Li's article highlights on how anxiety affects students on vocabulary recalling activity. Meanwhile, there are still many factors that should be taken into consideration to counterpart that issue, such as learners' age, motivation, learning strategies and learning styles to be considered for enhancing language learning. Moreover, this paper aims to provide other factors that may contribute in acquiring language in a different point of views.

\section{HONG LI'S PROPOSALS AND COMMENTS}

Hong Li (2015) has concluded that foreign language anxiety generally led to deficits in output performance. However, the effect of high anxiety-producing situation on language learners could be viewed as facilitative. The study findings indicate the negative effects of language anxiety on learner performance at the output stage and imply that some level of language anxiety may not be as negative and debilitative as expected. Pedagogically, language learners who are high in the anxiety measure can improve their language performance on a test by being given more time to compensate for their misdirected attention during the long-term memory retrieval process.

To strengthen the issue discussed by Hong Li that anxiety affects learners' acquisition of language learning, it is necessary to elicit further views from different perspective. Respecting the issue, this paper will emphasize more on other factors related to process of acquiring the language, such as learners' age, motivation, learning strategies, and learning styles.

\section{SEVERAL FACTORS INFLUENCE LANGUAGE LEARNING}

An individual difference that is believed to play a key role in second language learning is age. It is commonly thought that younger language learners are more successful and indeed researchers have found a relationship between age of acquisition and ultimate attainment in at least some aspects of the second language, with age showing itself to be the strongest predictor of success. Furthermore, Birdsong, 1999; Scovel, 2000; Singleton, 2001, as cited in Troike, 2006) have listed several advantages for both young and older learners:

\section{Younger advantage}

Brain plasticity

Not analytical

Fewer inhibitions

Weaker group identity

Simplified input more likely
Older advantage

Learning capacity

Analytic ability

Pragmatic skills

Greater knowledge of L1

Real-world knowledge

Yet, children acquiring the second language in natural environments are more likely to eventually sound like native speakers than adults are. Adults may appear to make greater progress initially, but children nearly always surpass them (Dulay et al., 
1982). Therefore, the results of researches regarding age should be considered by educational policy makers on the decisions related to the proper time in offering second language instruction to students.

Withal, in the area of second language acquisition research, the critical period hypothesis has been taken into consideration in age-related studies. There is believed to be a period up to a certain age during which learners can acquire a second language easily and achieve native-speaker-like competence. Besides, critical period hypothesis suggests that there is a time in human development when the brain is predisposed for success in language learning (Lightbown and Spada, 2001).

Accordingly, Lenneberg (1967, as cited in as cited in Troike, 2006) speculated that the critical period applies to SLA as well as to first language acquisition and that this accounts for why most all L2 speakers have a foreign accent if they do not begin learning the language before the cut-off age. However, the critical period hypothesis has been predominantly used in first language acquisition, whilst the sensitive period hypothesis has been generally restricted to second language acquisition. Even though the younger is believed to achieve better than older in language acquisition, Lightbown and Spada (2001) stated that older learners can attain high, if not native, level of proficiency in the second language. Accordingly, it is essential to be taken into account about the goals of an instructional program and the context in which it occurs for the better result.

Nevertheless, alluding to the process of acquiring language, motivation also has been considered as the factor affects learners' language acquisition. It is common to hear that the success or failure of a language learner to master a second language depends on their motivation. Motivation is usually associated with commitment, enthusiasm, and persistence to achieve goals. Moreover, Oxford Online Dictionary defines motivation as the "desire or willingness to do something" (Motivation, 2014). The Psychology Dictionary Online defines motivation as the driving force setting a direction to the behaviour of humans and animals at a conscious and unconscious level, and the willingness of a person to achieve a goal at a physical or mental level (Motivation, n.d.). Besides, motivation, as stated by Ehrman and Dornyei (1993, 2001, as cited in Troike, 2006) is also defined as a significant goal or need, desire to attain the goal, perception that learning L2 is relevant to fulfilling the goal or meeting the need, belief in the success or failure of learning L2, and value of potential outcomes

In line with this, Ariyanti's study (2016) revealed that students had lack of motivation which affects their decision whether they will speak in English. Therefore, teachers play a relevant role in this process as they should know how to motivate students. Besides, Putri (2014) has conducted a research on the correlation between anxiety as one of the psychological factors and students' speaking performance. As a result, there is a significant positive correlation between low anxiety score got by the students and their speaking performance and significant negative correlation between the students who got high anxiety score and their speaking performance. In other words, psychological factors are potential to affect the students' oral performance in negative ways. Not only in speaking, but motivation affects also in reading skill, as studied by Setianingsih (2017) found there is a significant effect of 
the learner's motivation toward the vocabulary mastered controlling for the reading literacy.

However, motivation generally determines the level of effort which learners expend at various stages in their L2 development. As stated by Nemati (2016), attitude and motivation are the most important determinant factors in learning or acquisition of second languages. Further, in her study, she questioned the impact of portfolio keeping on motivation in reading ability and the result was that portfolio keeping has positive effect on attitude/motivation of learners. Unfortunately, it is said that keeping students motivated is the second most complicated challenge for teachers (Hadfield \& Dornyei, 2013).Withal, Krashen (1985:4) stated that everybody needs motivation; everybody needs to have a reason for action. It is a sad fact that most people in this world underachieve because they do not believe they are capable of fulfilling their dreams. We teachers need to be committed offering students the opportunity to believe in themselves and achieve great things.

Additionally, motivation, as stated by Ellis (1997), involves the attitudes and affective states that influence the degree of effort that learners make to learn L2. Yet, motivation is also affected by the social dynamic or power relationship between the languages. Children, as well as adults, are sensitive to social dynamic and power relationship (Lightbown and Spada, 2001). Dörnyei (2005:65, as cited in Setianingsih, 2017) added that motivation helps learners cope with "long and tedious learning process" and provide learners help to achieve the long term goals in every learning process.

Along with this, Troike (2006) classified motivation into two types; integrative and instrumental motivation. Integrative motivation is based on interest in learning L2 because of desire to learn about or associate with people who use it, or because of an intention to participate or to integrate into the L2-using speech community. On the other hand, instrumental motivation involves perception purely practical value in learning the L2.

Yet, both integrative and instrumental motivation are essential elements of success, it is integrative motivation which has been found to sustain long-term success when learning a second language (Taylor, Meynard and Rheault, 1977; Ellis, 1997; Crookes and Schmidt, 1991). In some of the early research conducted by Gardner and Lambert, integrative motivation was viewed as being of more importance in a formal learning environment than instrumental motivation (Ellis 1997). In later studies, integrative motivation has continued to be emphasized, although now the importance of instrumental motivation is also stressed. However, it is important to note that instrumental motivation has only been acknowledged as a significant factor in some research, whereas integrative motivation is continually linked to successful second language acquisition. It has been found that, generally, students select instrumental reasons more frequently than integrative reasons for the study of language. Those who do support an integrative approach to language study are usually more highly motivated and overall more successful in language learning.

Regarding the motivation, Brown (2000) makes the point that both integrative and instrumental motivations are not necessarily mutually exclusive. Learners rarely select one form of motivation when learning a second language, but rather a 
combination of both orientations. He cited the example of international students residing in the United States, learning English for academic purposes while at the same time wishing to become integrated with the people and culture of the country. Overall, motivation is an important factor in L2 achievement. For this reason, it is important to identify both the type and combination of motivation that assists in the successful acquisition of a second language. At the same time, it is necessary to view motivation as one of a number of variables in an intricate model of interrelated individual and situational factors which are unique to each language learner.

Moreover, Ellis (1997) also identified motivation into four types: instrumental, integrative, resultative, and intrinsic. Instrumental motivation seems to be the major force determining success in L2 learning due to the learners may make efforts to learn an L2 for some functional reason, while integrative motivation related to the decision the learners choose to learn a particular L2 because they are interested in the people or culture represented by the target language group. On the other hands, resultative motivation is defined as the motivation which is resulted after learning. In this case, learners who experience success in learning may become more or perhaps less motivated to learn. The last but not least, is the intrinsic motivation. It refers to the motivation that involves the arousal of such factors as learners' particular interests and which they feel personally involved in learning activities.

Nevertheless, learners with high motivation are better equipped for success. Low motivation raises the affective filter and forms a mental block that prevents comprehensible input. When the filter is up, it impedes language acquisition. After all, motivation is not something that learners have or do not have but rather something that varies from one moment to the next depending on the learning task.

Howbeit, different L2 outcome may also be affected by individuals' learning strategies. Learning strategies are influenced by the nature of their motivation, cognitive style, and personality, as well as by specific contexts of use and opportunities for learning (Troike, 2006). Besides, learning strategies stated by Ellis (1997) refers to the particular approaches or techniques that learners employ to try to learn an L2; they can be behavioural or mental. According to the statement above, learners employ learning strategies when they are faced with some problem, and they generally aware of the strategies they use and what they did to try to learn something.

Notwithstanding, Chamot (1987, as cited in Troike, 2006) formulated a typology of language-learning strategies which is widely used in SLA:

- Metacognitive: are attempted to regulate language learning by planning and monitoring.

- Cognitive: make use of direct analysis or synthesis of linguistic material.

- Social/affective: involve interaction with others.

Furthermore, Ellis (1997) also identified different kinds of learning strategies:

- Cognitive strategies, which are involved in the analysis, synthesis, or transformation of learning materials. An example is 'recombination', which involves constructing a meaningful sentence by recombining known elements of the L2 in a new way.

- Metacognitive strategies are those involved in planning monitoring and evaluating 
learning. An example is 'selective attention', where the learner makes a conscious decision to attend to particular aspects of the input.

- Social/affective strategies concern the ways in which learners choose to interact with other speakers. An example is 'questioning for clarification', which learners are asking for repetition, a paraphrase, or an example.

After all, several studies have shown, not surprisingly, that successful learners use more strategies rather than unsuccessful learners. They may also call on different strategies at different stages of their development. Moreover, the learning strategies may also be influenced by age, sex, and many others aspects in acquiring language.

Remarkably, in learning language, learners have clear preferences for how they go about learning new material. The way of the language acquisition will also depend on learners' learning styles. In relation to this, Keefe (1987 as cited in Nzesei, 2015) stated that learning styles have been defined as a consistent way of functioning that reflects the underlying causes of learning behaviour. Learning style is both a characteristic which indicates how a student learns and likes to learn, as well as instructional strategy informing the cognition, context and content of learning. Besides, the term learning style has been used to describe an individuals' natural, habitual, and preferred way of absorbing, processing, and retaining new information and skills (Reid, 1995 as cited in Lightbown and Spada, 1999).

Exceedingly, some research has initiated those systematic differences in results variation in the way learners acquire new language may emerge from differences in learning style and aptitude (Meara et al., 2001 as cited in Milton, 2009). Along with this, study conducted by Kucukler (2016) found that learning styles of students give impact to their foreign language learning. Therefore, the process of acquiring new language will vary from one learner to another.

Aside of this, utilizing awareness of learners' learning styles within the educational background promotes more effective learning and hence improved academic achievement. Potentially, the most attractive claim is that teachers will be able to match their teaching to their learners' learning styles by explaining and presenting things in different ways using alternative teaching aids and techniques and tailoring the activities that they provide to suit their students learning styles. Greater awareness of their own dominant learning styles can help teachers to provide learning activities that are more inclusive of the other styles and which reach all students. Therefore, teachers should pay closer attention to this case because it can encourage learners to reflect on them so that the learners will become more motivated to learn by knowing their strengths and weaknesses and also the acquiring process of the new language become more optimal.

\section{CONCLUSIONS}

This paper has addressed the issue of how anxiety affects language learning. It examines the issue by reviewing Hong Li's article (2015). To condense, many factors should be taken into account to enhance the process of acquiring a language such as learners' age, motivation, learning strategies, and learning styles. However, the successful of learners in SLA is also influenced by those factors. Overall, teachers 
should encourage learners to alleviate their anxiety. Hence, other factors which may also affect their process of acquiring language should be paid attention carefully by the teacher so that the teaching learning process could run as well as what has been expected.

\section{REFERENCES}

Ariyanti, A. (2016). Psychological Factors Affecting EFL Students' Speaking Performance. Asian TEFL, Vol. 1 (1), 77-88.

Brown, H.D. (2000). Principles of language learning and teaching (4th Ed.). Englewood Cliffs NJ: Prentice-Hall.

Crookes, G., \& Schmidt R. W. (1991). Motivation: Reopening the research agenda. Language Learning, 41(4), 469-512.

Dulay, H., Burt, M., and Krashen, S. (1982). Language Two. Oxford: Oxford University Press.

Ellis, R. (1997). Second Language Acquisition. Oxford: Oxford University Press.

Hadfield, J., \& Dornyei, Z. (2013). Motivating Learning: Research And Resources in Language Teaching. Harlow, UK: Pearson.

Hong Li, C. (2015). The Effect of Anxiety on University-Level L2 Learner Ability to Recall Items in the Lexicon. The Journal of Language Teaching and Learning, Vol. 5(1), 24-33.

Krashen, S. (1985). The input hypothesis: Issues and implications. UK: Longman.

Lightbown, P., and Spada, N. (2001). How Languages Are Learned Second Edition. Oxford: Oxford University Press.

Macintyre, P. (1995). How Does Anxiety Affect Second Language Learning? A Reply to Sparks and Ganschow. The Modern Language Journal, 79, 90-99.

Milton, J. (2009). Measuring Second Language Vocabulary Acquisition. Great Britain: Short Run Press Ltd.

Motivation. (2014). In Oxford Online Dictionary. Retrieved from http://www.oxforddictionaries.com/definition/english/motivation?q=moti vation

Motivation. (n.d.). In Psychology Dictionary Online. Retrieved from http://psychologydictionary.org/letter/m/page/97/

Nemati, Azadeh. (2016). Portfolio Keeping Ends to a Good Product: The Cases of Reading and Motivation. Asian TEFL, Vol.1(2), 187-198.

Nzesei, M. (2015). A Correlation Study between Learning Styles and Academic Achievement among Secondary School Students in Kenya. The University of Nairobi.

Putri, P. L. (2014). A Study on Students' Anxiety and Its Correlation with the Speaking Performance of XI Grade Students at SMAN 1 KRIAN. Brawijaya University. Jurnal Mahasiswa Ilmu Budaya Vol. 6 (15).

Setianingsih, I. S. (2017). Factors Affecting the English Reading Literacy of Junior High School Students. IJELTAL (Indonesian Journal of English Language Teaching and Applied Linguistics), Vol. 1(2), 165-185.

Troike, M. (2006). Introducing Second Language Acquisition. Cambridge: 
Language Learning: What Factors May Influence It

Cambridge University Press.

Taylor, D. M., Meynard, R., \& Rheault, E. (1977). Threat to ethnic identity and second-language learning. In $\mathrm{H}$. Giles, Language, ethnicity and intergroup relations (pp. 99-118). Academic Press. 